\title{
UPAYA MENINGKATKAN KEMAMPUAN PEMAHAMAN MATEMATIK SISWA MELALUI MODEL PEMBELAJARAN KOOPERATIF STAD BERBANTUAN GEOBOARD MATERI SEGI EMPAT DAN SEGITIGA
}

\author{
Novita Marlina Damanik \\ Universitas Katolik Santo Thomas, Medan; \\ vitamanik105@gmail.com
}

\begin{abstract}
Abstrak. Penelitian ini bertujuan untuk mengetahui peningkatan kemampuan pemahaman matematik siswa di kelas VII-2 SMP Santo Thomas 3 Medan dengan menerapkan model pembelajaran kooperatif tipe STAD berbantuan geoboard. Metode yang digunakan dalam penelitian ini adalah penelitian tindakan kelas (PTK). Subjek pada penelitian ini yaitu siswa kelas VII-2 SMP Swasta Santo Thomas 3 Medan tahun pelajaran 2018/2019 yang terdiri dari 32 siswa yaitu lakilaki 18 orang dan perempuan 14 orang. Dari hasil penelitian dapat dilihat adanya peningkatan kemampuan pemahaman siswa dengan menerapkan model pembelajaran kooperatif tipe STAD berbantuan geoboard sebagai berikut: Pada tes kemampuan pemahaman awal matematik siswa masih tergolong rendah yaitu diperoleh ketuntasan klasikal sebesar 18,75\% dengan kategori sangat rendah. Hasil tes pemahaman matematik siswa siklus I yaitu diperoleh ketuntasan klasikal sebesar 53,12\% dengan kategori sedang. Hasil tes pemahaman matematik siswa siklus II yaitu diperoleh ketuntasan klasikal sebesar $84,37 \%$ dengan kategori tinggi. Hal tersebut dapat dilihat bahwa terjadi peningkatan mulai dari kemampuan pemahaman awal, kemampuan pemahaman matematik siklus I dan kemampuan pemahaman matematik siklus II. Sehingga dapat disimpulkan bahwa peningkatan kemampuan pemahaman matematik siswa melalui model pembelajaran kooperatif tipe STAD berbantuan geoboard meningkat dari siklus I ke siklus II, sebesar $31,25 \%$.
\end{abstract}

Kata Kunci. Model pembelajaran, kooperatif STAD, pemahaman.

Abstract. This study aims to determine the improvement of students' mathematical understanding abilities in class VII-2 SMP St. Thomas 3 Medan by applying the cooperative learning model type STAD assisted by geoboard. The method used in this research is classroom action research (CAR). The

Cartesius: Jurnal Pendidikan Matematika Vol. 2 No. 2

CProdi Pendidikan Matematika Universitas Katolik Santo Thomas 
subjects in this study were students of class VII-2 St. Thomas Private School 3 Medan in the 2018/2019 Academic Year consisting of 32 students, 18 men and 14 women. From the research results it can be seen that there is an increase in students in students' understanding ability by applying the geoboard-assisted type STAD cooperative learning model as follows: In the students' mathematical early comprehension ability test is still realatively low, namely classical completeness obtained by $18.75 \%$ with very low categories. The results of the first cicle students' mathematical understanding test that is obtained classical completeness of $53.12 \%$ with the medium category The results of the second cycle mathematical understanding test students obtained classical completeness of $84.37 \%$ with a high category. It can be seen that there is an increase starting from the ability of initial understanding, the ability to understand mathematical cycle I and mathematical understanding ability ability cycle II. So it can be concluded that the increase in students mathematical understanding abilities through the Geoboard-assisted STAD cooperative learning model increased from cycle I to cycle II, amounting to $31.25 \%$

Keywords. Learning model, cooperative STAD, understanding.

\section{PENDAHULUAN}

Pendidikan merupakan salah satu hal penting untuk dilalui setiap orang dalam meningkatkan sumber daya manusia yang berkualitas. Menurut UU No. 20 Tahun 2003 pasal 3 (dalam Trianto, 2011:1) menyatakan "pendidikan nasional berupaya mengembangkan kemampuan dan membentuk watak serta peradaban bangsa yang bermartabat dalam rangka mencerdaskan kehidupan bangsa. Oleh karena itu, pendidikan bertujuan untuk mengembangkan potensi peserta didik agar menjadi manusia yang beriman dan bertakwa kepada Tuhan Yang Maha Esa.

Dalam mengembangkan potensi peserta didik harus mengikuti Perkembangan ilmu pengetahuan dan teknologi (IPTEK) karena IPTEK berdampak pada semua kehidupan. Selain perkembangan yang pesat, perubahan juga terjadi dengan cepat. Karenanya diperlukan kemampuan untuk memperoleh, mengelola dan memanfaatkan IPTEK tersebut secara proposional. Kemampuan ini membutuhkan pemikiran yang sistematis, logis, dan kritis yang dapat dikembangkan melalui peningkatan mutu pendidikan. Pemikiran yang sistematis, logis, dan kritis penting dalam matematika, sebagaimana Susanto (2013: 183) mengemukakan bahwa

Cartesius: Jurnal Pendidikan Matematika Vol. 2 No. 2

CProdi Pendidikan Matematika Universitas Katolik Santo Thomas 
matematika merupakan salah satu mata pelajaran yang sangat penting dalam dunia pendidikan karena dengan belajar matematika siswa mampu mengembangkan potensi dirinya yaitu berfikir aktif dan logis. Maka dari itu, matematika diajarkan mulai dari tingkat Sekolah Dasar, Sekolah Menengah Pertama, Sekolah Mmenengah Atas, bahkan sampai keperguruan tinggi.

Pembelajaran matematika berdasarkan NCTM (dalam Fatrima, 2017: 49) memiliki tujuan yaitu: pertama, pemecahan masalah matematika (mathematical problem solving); kedua, penalaran dan pembuktian matematika (mathematical reasoning and proof); ketiga, komunikasi matematika (mathematical communication); keempat, koneksi matematis (mathematical connections); dan kelima, representasi matematis (mathematics representation).

Faktanya kemampuan pemahaman matematik siswa masih rendah. Apabila kemampuan pemahaman rendah maka hasil belajar siswa akan rendah pula. Hal ini sejalan dengan pendapat Kesumawati (dalam Ningsih, 2016: 1) "menyatakan bahwa landasan penting yang harus dimiliki oleh peserta didik dalam usahanya untuk berpikir menyelesaikan permasalahan matematika maupun permasalahan dalam kehidupan sehari-hari, adalah kemampuan dalam memahami matematika".

Hal ini diketahui dari hasil observasi pada proses kegiatan belajar mengajar di kelas VII 2 SMP Santo Thomas 3 Medan. Guru masih menggunakan pembelajaran konvensional. Guru menjelaskan dan memberikan contoh, selanjutnya siswa diminta untuk mengerjakan soal di buku tugas yang telah tersedia. Pembelajaran konvensional mengakibatkan siswa banyak tingkah yang kurang baik dalam proses belajar mengajar. Banyak siswa yang takut untuk bertanya yang belum dimengerti atau takut memberikan pendapat. Banyak dari mereka lebih memilih mencatat dan mendengarkan pada saat proses pembelajaran berlangsung, sehingga siswa merasa bosan atau jenuh pada pembelajaran matematik yang dianggap kurang menarik.

Selanjutnya dilakukan wawancara dengan salah satu guru matematika di sekolah tersebut yaitu ibu S. Sagala, S.Pd di kelas VII-2 SMP Santo Thomas 3 Medan bahwa banyak masalah - masalah yang dihadapi siswa maupun guru

Cartesius: Jurnal Pendidikan Matematika Vol. 2 No. 2

@Prodi Pendidikan Matematika Universitas Katolik Santo Thomas 
dalam pembelajaran matematika. Sesuai dengan informasi dari ibu S. Sagala, S.Pd siswa malas jika belajar matematika karena mereka menganggap matematika itu sangat membosankan dan susah untuk dipelajari. Siswa masih sulit untuk mengaplikasikan soal kedalam kehidupan sehari - hari karena pada kurikum 2013 siswa dituntut untuk mampu mengaplikasikan kehidupan sehari - hari dan jika guru memberikan soal maka siswa sulit untuk menyelesaikan masalah tersebut karena mereka dari SD sudah terbiasa mengerjakan soal dengan bahasa matematika. Siswa mudah lupa jika guru menjelaskan di depan ruangan kelas, jika siswa diminta menjelaskan kedepan siswa sulit untuk mengungkapkan apa yang sudah dijelaskan, malu untuk berbicara, takut melihat guru. Sesuai hasil wawancara dengan ibu S. Sagala, S.Pd banyak siswa mendapat nilai dibawah KKM yaitu 70.

Berdasarkan masalah - masalah yang dihadapi siswa kelas VII-2 SMP Santo Thomas 3 Medan dalam pembelajaran matematika yaitu salah satu masalah yang dihadapi adalah mengenai pemahaman matematika tanpa adanya pemahaman maka siswa tidak dapat mengerjakan soal dari yang mudah sampai yang sulit. Disini peneliti bermaksud untuk melihat sejauh mana pemahaman siswa kelas VII-2 jika diberikan soal cerita dalam pembelajaran. Selanjutnya peneliti memberikan soal minites kepada siswa kelas VII- 2 sebanyak 32 orang siswa tetapi 1 orang dari 32 siswa tidak hadir kerena sakit sehingga siswa yang mengikuti minites yaitu 31 orang, jumlah soal sebanyak 5 butir soal essai.

Adapun hasil minites siswa yaitu: tidak ada siswa yang mendapat nilai 90100 dengan kriteria sangat baik, 4 orang siswa (12,9\%) mendapat nilai 75-89 dengan kriteria baik, 9 orang siswa (29\%) mendapat nilai 55-74 dengan kriteria cukup, 10 orang siswa (32,2\%) mendapat nilai 40-54 dengan kriteria kurang, 8 orang siswa $(25,8 \%)$ mendapat nilai 0-39 dengan kriteria sangat kurang. Berdasarkan hal ini maka $74,5 \%$ siswa masih belum memiliki kemampuan pemahaman matematik. Ini menunjukkan suatu kemampuan pemahaman matematik siswa di SMP Santo Thomas 3 Medan masih rendah. Salah satu upaya yang dapat dilakukan untuk meningkatkan kemampuan pemahaman matematik adalah menerapkan model pembelajaran kooperatif

Cartesius: Jurnal Pendidikan Matematika Vol. 2 No. 2

CProdi Pendidikan Matematika Universitas Katolik Santo Thomas 
tipe STAD. Hal ini sesuai dengan hasil penelitian terdahulu yang mengungkapkan keunggulan dari model pembelajaran kooperatif tipe STAD. Hasil penelitian yang dilaksanakan oleh Nida Jarmita (2012) mengungkapkan bahwa terdapat perbedaan peningkatan kemampuan pemahaman matematis antara siswa yang mengikuti pembelajaran kooperatif tipe STAD dengan siswa yang mengikuti pembelajaran konvensional ditinjau dari level sekolah (baik, sedang,dan kurang). Dimana peningkatan kemampuan pemahaman matematis antar level sekolah yang memperoleh pembelajaran kooperatif tipe STAD lebih baik daripada peningkatan kemampuan pemahaman matematis antar level sekolah yang memperoleh pembelajaran biasa.

Menurut Trianto (2011 : 68) STAD adalah model pembelajaran dimana siswa ditempatkan dalam tim-tim belajar beranggotakan empat sampai lima siswa yang heterogen. Tipe pembelajaran ini menekankan adanya aktivitas dan interaksi diantara siswa untuk saling memotivasi dan saling membantu dalam menguasai materi pelajaran untuk mencapai prestasi yang maksimal. Proses pembelajaran tipe ini melalui enam tahapan, meliputi : 1) tahap menyampaikan tujuan dan memotivasi siswa, 2) tahap penyajian materi, 3) tahap kegiatan kelompok, 4) tahap tes individual, 5) tahap penghitungan skor perkembangan individu, dan 6) tahap pemberian penghargaan kelompok.

Model pembelajaran kooperatif tipe STAD berbantuan geoboard baik diterapkan untuk meningkatkan kemampuan pemahaman matematik siswa. Geoboard adalah salah satu media yang dapat membantu guru dalam meningkatkan pemahaman. Geoboard merupakan alat untuk menyalurkan materi yang akan diajarkan untuk merangsang kreativitas siswa. Belajar menggunakan geoboard adalah belajar sambil bermain. Belajar sambil bermain memiliki nilai yang baik dalam penerapannya. Belajar sambil bermain memudahkan siswa untuk mengingat dan memahami materi yang telah diajarkan di sekolah. Menurut Winasis (dalam Dolhasair dkk, 2017: 2) geoboard ini memiliki keunggulan, yaitu sebagai alat bantu guru. Pembuatan media ini mudah. Dengan geoboard, siswa lebih mudah mengingat materi

Cartesius: Jurnal Pendidikan Matematika Vol. 2 No. 2

CProdi Pendidikan Matematika Universitas Katolik Santo Thomas 
yang disampaikan, siswa mudah mengelompokkan bentuk bangun datar, siswa lebih terampil, tahan lama, dan bahannya mudah didapat.

Berdasarkan penelitian yang dilakukan oleh Titin Faridatun Nisa (2015) Hasil analisis data nilai Post Test dari kelompok kontrol dan eksperimen menunjukkan $t_{\text {hitung }}(-10,789)<t_{\text {tabel }}(2,042)$, sehingga H0 ditolak. Berdasarkan nilai Post Test menunjukkan adanya perbedaan hasil belajar siswa yang menggunakan Geoboard bangun datar dalam pembelajaran matematika bila dibandingkan dengan yang menggunakan gambar bangun datar. Peningkatan hasil belajar siswa pada kelas eksperimen lebih tinggi dibandingkan kelas kontrol. Hasil analisis angket respon siswa menunjukkan presentase rata-rata 8,438 dengan kategori sangat baik, sehingga pembelajaran matematika menggunakan geoboard ini dikategorikan efektif dengan tinjauan tes hasil belajar meningkat dan respon siswa sangat baik.

Berdasarkan penjelasan sebelumnya, disimpulkan bahwa tanpa pemahaman yang baik siswa tidak mampu menyelesaikan masalah - masalah matematik. Dengan demikian, perlu dilakukan penelitian terkait dengan upaya meningkatkan kemampuan pemahaman matematik siswa melalui model pembelajaran kooperatif tipe student teams achiement division (STAD) dengan berbantuan geoboard pada materi segiempat dan segitiga di kelas VII SMP.

\section{METODE}

Metode penelitian yang digunakan yaitu penelitian tindakan kelas. Menurut Tampubolon (2014: 19) menyatakan bahwa penelitian tindakan kelas adalah penelitian yang dilaksanakan oleh pendidik/calon guru di ruangan kelasnya sendiri secara kolaboratif/partisipatif untuk memperbaiki kinerja pendidik menyangkut kualitas proses pembelajaran, dan meningkatkan hasil belajar peserta didik menyangkut kualitas proses pembelajaran, dan meningkatkan hasil belajar peserta didik, baik dari aspek akademik maupun nonakademik, melalui tindakan reflektif dalam bentuk siklus. Dapat disimpulkan bahwa Penelitian Tindakan Kelas adalah penelitian yang dilakukan oleh pendidik

Cartesius: Jurnal Pendidikan Matematika Vol. 2 No. 2

CProdi Pendidikan Matematika Universitas Katolik Santo Thomas 
atau calon pendidik dalam proses pembelajaran di dalam kelas yang dapat meningkatkan hasil belajar siswa.

Pada penelitian tindakan kelas ini diharapkan dapat meningkatkan kualitas siswa baik dalam aspek pemahaman, maupun aspek-aspek lain yang bermanfaat bagi siswa untuk menjadi dewasa seutuhnya. Adapun prosedur penelitian tindakan kelas dengan model Kemmis dan McTaggart yang terdiri dari perencanaan tindakan (planning), pelaksanaan tindakan (acting), observasi (observing), dan refleksi (reflecting) Saur (2013 : 27). Dalam penelitian ini menggunakan penelitian kolaboratif yaitu guru bersama peneliti berkolaborasi dalam melakukan penelitian tindakan kelas ini.

Subjek pada penelitian ini yaitu siswa kelas VII-2 SMP Swasta Santo Thomas 3 Medan tahun pelajaran 2018/2019 yang terdiri dari 31 siswa yaitu laki-laki 17 orang dan perempuan 14 orang. Objek penelitian ini adalah menerapkan model pembelajaran kooperatif tipe STAD berbantuan geoboard dan kemampuan pemahaman matematik.

Teknik pengumpulan data yang digunakan calon peneliti pada penelitian ini adalah tes dan non-tes. Teknik tes dalam penelitian ini menggunakan tes awal dan tes kemampuan pemahaman matematik pada setiap siklus. Soal tes berbentuk uraian sebanyak 5 soal disusun sesuai indikator kemampuan pemahaman matematik. Selanjutnya, teknik non-tes yang dimaksud pada penelitian ini menggunakan lembar observasi aktivitas guru dan siswa.

\section{HASIL DAN PEMBAHASAN}

\section{Tahap Pelaksanaan Tindakan Siklus I}

Hasil tes siswa pada tes awal, siklus I dan tes siklus II setiap tes diberikan 5 soal uraian, pada setiap soal terdapat indikator pemahaman matematik siswa. Secara keseluruhan hasil perolehan nilai rata - rata siswa pada tes awal, siklus I, tes siklus II dapat pada tabel berikut:

Cartesius: Jurnal Pendidikan Matematika Vol. 2 No. 2 
Tabel 1. Tingkat Kemampuan Pemahaman Matematik

\begin{tabular}{|lccc|}
\hline \multicolumn{1}{|c}{ Kategori } & Tes Awal & Tes Siklus I & Tes Siklus \\
Nilai Terendah & & & II \\
Nilai Tertinggi & 25 & 40 & 55 \\
Jumlah Siswa yang Tuntas & 80 & 85 & 95 \\
Jumlah Siswa yang Tidak & 6 Siswa & 17 Siswa & 27 Siswa \\
Tuntas & 26 Siswa & 15 Siswa & 5 Siswa \\
Rata-rata & $\mathbf{5 2 , 0 3}$ & $\mathbf{6 2 , 8 1}$ & $\mathbf{7 2 , 5}$ \\
Ketuntasan Klasikal & $\mathbf{1 8 , 7 5 \%}$ & $\mathbf{5 3 , 1 2 \%}$ & $\mathbf{8 4 , 3 7 \%}$ \\
\hline
\end{tabular}

Dari tabel 1. dapat dilihat bahwa terjadi peningkatan yang diperoleh siswa dari tes awal, tes siklus I sampai tes siklus II. Pada nilai terendah siswa dan nilai tertinggi siswa adanya peningkatan dimana nilai terendah siswa juga terjadi peningkatan pada tes awal 25, siklus I bernilai 40 dan siklus II menjadi 55. nilai tertinggi juga meningkat pada tes awal 80, siklus I 85 dan siklus II 95. Jumlah siswa yang tuntas juga adanya peningkatan pada tes awal, siklus I dan siklus II yaitu mulai dari 6 orang siswa menjadi 17 orang siswa dari 17 orang menjadi 27 orang siswa. Pada siswa yang tidak tuntas terjadi penurunan dari tes awal, siklus I sampai siklus II. Ketuntasan klasikal juga adanya peningkatan tes awal 18,75\%, disiklus I 53,12\% menjadi 84,37\%. Dalam setiap siklus dilakukan observasi atau pengamatan kepada guru selama proses pembelajaran berlangsung. Pengamatan dilakukan oleh guru bidang studi matematika juga disebut sebagai pengamat atau observer pada penelitian. Observer memberikan penilaian kepada peneliti yang bertindak sebagai guru dengan mengisi lembar observasi aktivitas guru. Pada setiap siklus dilakukan observasi aktivitas guru sebanyak dua kali sesuai dengan pertemuan pada masing-masing siklus. Berikut tabel perbandingan hasil persentase observasi aktivitas guru pada siklus I dan siklus II:

Cartesius: Jurnal Pendidikan Matematika Vol. 2 No. 2

CProdi Pendidikan Matematika Universitas Katolik Santo Thomas 
Tabel 2. Observasi Aktivitas Guru pada Siklus I dan Siklus II

\begin{tabular}{|lcccc|}
\hline \multicolumn{1}{c}{ Pertemuan } & \multicolumn{2}{c}{ Siklus I } & \multicolumn{2}{c|}{ Siklus II } \\
& Presentase & Kriteria & Presentase & Kriteria \\
Pertama & $72,91 \%$ & Cukup & $85 \%$ & Baik \\
Kedua & $79,16 \%$ & Baik & $88 \%$ & Sangat Baik \\
Rata-rata Nilai & $\mathbf{7 6 , 0 3 \%}$ & Baik & $\mathbf{8 6 , 5 \%}$ & Sangat Baik \\
\hline
\end{tabular}

Dari tabel 2. dapat dilihat bahwa adanya peningkatan pada observasi aktivitas guru dalam siklus I dan siklus II. Pada siklus I rata-rata nilai observasi aktivitas guru yaitu 76,03\% dengan kriteria baik selanjutnya pada siklus II terjadi peningkatan menjadi $86,5 \%$ dengan kriteria sangat baik.

Setiap dilakukan pengamatan terhadap siswa selama proses pembelajaran berlangsung. Pengamatan dilakukan oleh guru bidang studi matematika sebagai observer pada penelitian. Observer memberikan penilaian terhadap siswa dengan mengisi lembar observasi aktivitas siswa. Pada tiap siklus dilakukan observasi aktivitas siswa sebanyak dua kali sesuai dengan pertemuan pada tiap siklus. Perbandingan hasil persentase observasi aktivitas siswa pada siklus I dan siklus II sebagai berikut:

Tabel 3. Hasil Observasi Aktivitas Siswa pada Siklus I dan Siklus II

\begin{tabular}{|lcccc|}
\hline \multicolumn{1}{c}{ Pertemuan } & \multicolumn{2}{c}{ Siklus I } & \multicolumn{2}{c|}{ Siklus II } \\
& Presentase & Kriteria & Presentase & Kriteria \\
Pertama & $68,4 \%$ & Baik & $79,3 \%$ & Sangat Baik \\
Kedua & $75 \%$ & Baik & $86,9 \%$ & Sangat Baik \\
Rata-Rata Nilai & $\mathbf{7 1 , 7 \%}$ & Baik & $\mathbf{8 3 , 1 \%}$ & Sangat Baik \\
\hline
\end{tabular}

Dari tabel 3. dapat dilihat bahwa adanya peningkatan hasil observasi aktivitas siswa pada siklus I dan Siklus II. Pada siklus I rata-rata nilai observasi aktivitas siswa yaitu $71,7 \%$ dengan kriteria baik kemudian pada siklus II terjadi peningkatan menjadi $83,1 \%$ dengan kriteria sangat baik.

\section{KESIMPULAN}

Berdasarkan hasil penelitian yang sudah dilakanakan dengan menerapkan model pembelajaran kooperatif tipe Student Team Achievement Division (STAD) berbantuan geoboard di kelas VII-2 SMP Santo Thomas 3 Medan

Cartesius: Jurnal Pendidikan Matematika Vol. 2 No. 2

CProdi Pendidikan Matematika Universitas Katolik Santo Thomas 
menunjukkan terjadi peningkatan kemampuan pemahaman matematik siswa. Hal ini dapat dilihat dari:

1. Tingkat pemahaman matematik siswa di kelas VII-2 SMP Santo Thomas 3 Medan sebelum dan sesudah menerapkan model pembelajaran kooperatif tipe STAD berbantuan geoboard dapat disimpulkan meningkat, hal ini dapat dilihat tes kemampuan pemahaman matematik awal $18,75 \%$, tes kemampuan pemahaman matematik siswa siklus I 53,12\%, dan tes kemampuan pemahaman matematik siklus II 84,37\%.

2. Peningkatan yang terjadi pada observasi aktivitas guru diperoleh dari hasil observasi pada siklus I yaitu pertemuan pertama $72,91 \%$, pertemuan kedua 79,16\%, rata-rata observasi aktivitas guru 76,03\%. Observasi aktivitas guru pada siklus II yaitu pertemuan ketiga $85 \%$, pertemuan keempat $88 \%$ dengan, rata-rata observasi aktivitas guru yaitu $86,5 \%$.

3. Peningkatan yang terjadi pada observasi aktivitas siswa diperoleh dari hasil observasi pada siklus I yaitu pertemuan pertama $68,4 \%$, pertemuan kedua $75 \%$, rata-rata observasi aktivitas siswa yaitu 71,7\%. Observasi aktivitas siswa pada siklus II yaitu pertemuan ketiga $79,3 \%$, pertemuan keempat $86,9 \%$, rata-rata observasi aktivitas siswa yaitu $83,1 \%$.

Hal ini dapat disimpulkan dengan menggunakan model pembelajaran kooperatif tipe STAD berbantuan geoboard dapat meningkatkan kemampuan pemahaman matematik siswa pada materi segiempat dan segitiga di kelas VII-2 SMP Santo Thomas 3 Medan .

Adapun yang menjadi saran dalam pelaksanaan peneliti tindakan kelas dan hasil penelitian yang diperoleh peneliti adalah sebagai berikut:

1. Bagi Siswa disarankan lebih berani dalam memberikan ide - ide matematik dan aktif dalam kegiatan belajar mengajar sehingga menemukan solusi permasalahan selama proses pembelajaran berlangsung serta lebih mengembangkan kemampuan pemahaman matematik siswa dan kemampuan-kemampuan matematika yang lainnya.

2. Bagi Guru

Pembelajaran menggunakan model pembelajaran kooperatif tipe Student Team Achievement Division (STAD) berbantuan geoboard dapat mempermudah pemahaman siswa dengan menghubungkan kehidupan

Cartesius: Jurnal Pendidikan Matematika Vol. 2 No. 2

CProdi Pendidikan Matematika Universitas Katolik Santo Thomas 
sehari - hari dan lebih memahami model pembelajaran kooperatif tipe STAD berbantuan geoboard yang akan diterapkan di kelas dalam meningkatkan kemampuan pemahaman siswa dan dapat juga meningkatkan perhatian siswa bila guru menggunakan media pada saat pembelajaran di kelas.

3. Bagi Sekolah

Agar memberikan dukungan fasilitas yang baik dan sarana dan prasarana yang dapat meningkatkan kemampuan pemahaman matematik siswa dengan menerapkan model pembelajaran kooperatif tipe STAD berbantuan geoboard yang berdampak positif pada pembelajaran di dalam kelas.

4. Bagi Peneliti

Kepada peneliti selanjutnya yang berminat melakukan penelitian ini , agar menggunakan hasil dan perangkat untuk dijadikan pertimbangan dalam menerapkan model pembelajaran kooperatif tipe Student Team Achievement Division (STAD) berbantuan geoboard pada materi segiempat dan segitiga ataupun materi yang lain serta dapat dikembangkan oleh peneliti sebelumnya.

\section{UCAPAN TERIMAKASIH}

Terimakasih penulis sampaikan kepada program studi Pendidikan Matematika Universitas Katolik Santo Thomas dalam hal ini Dosen Pembimbing 1 yaitu Ibu Sinta Dameria Simanjuntak, S.Si., M.Pd. dan Dosen Pembimbing 2 yaitu Ibu Imelda, S.Pd., M.Pd. yang sudah membantu dalam penulisan skripsi dan artikel ini. Semoga hasil dari penelitian ini bermanfaat bagi perkembangan ilmu pengetahuan.

\section{DAFTAR PUSTAKA}

[1] Amawardini, dkk. 2017. Pengaruh Media Pembelajaran Geoboard Terhadap Hasil Belajar Siswa. Jurnal : Didaktika Tauhidi .Volume: 4. No, 2. ISSN 2550-0252, Html, diakes pada 31 Januari 2019, Jam 16:21 WIB.

[2] Arikunto. 2010. Prosedur Penelitian Suatu Pendekatan Praktik.Jakarta: Rineka Cipta.

[3] Arikunto. 2013. Dasar - Dasar Evaluasi Pendidikan.Jakarta: Bumi Aksara.

Cartesius: Jurnal Pendidikan Matematika Vol. 2 No. 2

CProdi Pendidikan Matematika Universitas Katolik Santo Thomas 
[4] Desi, Amelia, dkk. 2018. Kemampuan Pemahaman Matematis Siswa SMP di Bandung Barat. Jurnal: JPPM Vol: 11, No:1, Html, diakses pada 30 januari 2019, jam 01:15 WIB.

[5] Dolhasair. dkk. 2017. Penggunaan Media Geoboard (Papan Bepaku) Untuk Meningkatkan Pemahaman Konsep Bangun Datar Pada Siswa Kelas II Sekolah Dasar. Jurnal Didaktika Dwija Indria.ISSN : 2337-8786. Html, diakses pada 16 januari 2019 jam 06:45 WIB.

[6] Fatrima. 2017. Kemampuan Representasi Matematis Dan Kemampuan Pembuktian Matematika. Jurnal: Edumath, Vol: 3 No. 1, ISSN Online : 2356-2056. Html, diakses pada 23 Februari 2019, jam 14:01 WIB.

[7] Gulo, W. 2002. Strategi Belajar Mengajar. Jakarta: Grafindo.

[8] Gusniar. 2014. Penerapan Model Pembelajaran Kooperatif Tipe Student Teams Achievment Division (STAD) Dalam Meningkatkan Hasil Belajar Siswa Pada Mata Pelajaran IPS Kelas IV SDN No. 2 Ogoamas II.Jurnal Kreatif Tadulako Online Vol. 2 No. 1ISSN 2354-614X. Html, diakes pada 21 januari 2019 Jam 12:06 WIB.

[9] Hamdani. 2017. StrategiBelajarMengajar.Bandung : CV PustakaSetia.

[10]Icahiriza. 2015. Upaya Meningkatkan Hasil Belajar Matematika Siswa Kelas VII Melalui Model Pembelajaran Kooperatif Tipe STAD Di SMP Negeri 3 Pagaralam. Html, diakses pada 2 Maret 2019, jam 20:01 WIB.

[11]Huda, Miftahul. 2014. Model-Model PengajarandanPembelajaran.Yogyakarta :PustakaPelajar.

[12]Ika, Sriyanti. 2017. Peningkatan Kemampuan Pemahaman Matematik Siswa SMP PGRI Pemanukan Melalui Model Pembelajaran Kooperatif Tipe STAD. Jurnal: Pasundan Journal of Research in Mathematics Learning and Education. Vol: 2 No 2, ISSN 2548-2297. Html, diakses pada 30 januari 2019, jam 10:15 WIB.

[13]Jarmita, Nida. 2012. penerapan pembelajaran kooperatif tipe STAD dalam meningkatkan pemahaman matematis siswa pada pokok bahasan bangun ruang. Jurnal: lmiah didaktika. Vol: XIII, no. 1, 150-172. Html, diakses pada 31 Januari 2019, jam 17:42 WIB.

[14]Jihad,Asep \& Abdul Haris. 2018. Evaluasi Pembelajaran. Yogyakarta: Multi Presindo.

[15]Kunandar. 2010. Penilitian Tindakan Kelas. Jakarta: PT. Rajagrafindo Persada.

Cartesius: Jurnal Pendidikan Matematika Vol. 2 No. 2

○Prodi Pendidikan Matematika Universitas Katolik Santo Thomas 
[16]Kurniasih. 2016. Ragam Pengembangan Model Pembelajaran. Kata Pena.

[17]Masitoh 2018. Pengembangan Media Pembelajaran Papan Berpaku Untuk Meningkatkan Pemahaman Konsep Luas Bangun Datar. Jurnal:Bbtida'.Vol: 5 ,No. 01. Htlm, diakses pada 31 januari 2019, jam 16:00 WIB.

[18]Ningsih. 2016. Kemampuan Pemahaman Konsep Matematika Mahasiswa Melalui Penerapan Lembar Aktivitas Mahasiswa (LAM) Berbasis Teori APOS Pada Materi Turunan.Jurnal edumatica.vol: 06 No.01. Html, diakses pada 15 januari 2019, jam 03:45 WIB.

[19]Nisa, dkk. 2015. Efektivitas Penggunaan Geoboard Bangun Datar Dalam Pembelajaran Matematika. Jurnal Apotema. Vol: 1. No. 2.ISSN 2407-8840. Html, diakses pada 08 januari 2019 jam 14:43 WIB.

[20]Nursaadah, dkk. 2018. Analisis Kemampuan Pemahaman Matematis Siswa Smp Pada Materi Segitiga Dan Segiempat.Jurnal Numeracy.vol: 5 No.1. Html, diakes pada 15 Januari 2019,jam 01:44 WIB.

[21]Purwanto. 2017. Evaluasi Hasil Belajar.Yogyakarta :PustakaPelajar.

[22]Rusman. 2013. Model - Model Pembelajaran Mengembangkan Profesionalisme Guru.Jakarta: PT Raja Grafindo Persada.

[23]Rusman. 2017. Belajar E Pembelajaran.Bandung : Kencana.

[24]Sanjaya, Wina. 2013. Penelitian Pendidikan.Jakarta: Kencana.

[25]Sanjaya,Wina. 2013. Penelitian Tindakan Kelas.Jakarta: Kencana.

[26] Sari, isnaweni. Dkk.2017. pengaruh metode diskusi dengan alat peraga papan berpaku terhadap hasil belajar matematika siswa kelas VII SMP Muhammadiyah Limbung. Html, diakses pada 31 Januari 2019, jam 13:01 WIB.

[27]Sarjanti, Esti. Dkk. Peningkatan Aktivitas Dan Prestasi Belajar Siswa Melalui Metode Picture And Picture Dengan Media Audio Visual Pada Mata Pelajaran Geografi Di Kelas XI Ips 2 Sma Negeri 1 Bantarkawung. Jurnal: Geoedukasi Vol: IV, No: 2. Html, diakses pada 10 Maret 2019, Jam 13: 56 WIB.

[28]Setiawan. Dkk. 2013. kemampuan pemahaman matematik siswa smp melalui penerapan pembelajaran kooperatif tipe STAD. Jurnal: Pendidikan Informatika dan Sains, Vol: 2, No: $2 \mathrm{Html}$, diakses pada 18 Januari 2019, Jam 12: 56 WIB.

[29]Sipayung, T. N. \& Simanjuntak, T. N. 2018. Pengembangan Lembar Aktivitas Siswa (Las) Matematika Kelas X Sma Dengan Penerapan Variasi Model Pembelajaran Kooperatif. Jurnal: JNPM (Jurnal Nasional

Cartesius: Jurnal Pendidikan Matematika Vol. 2 No. 2

(CProdi Pendidikan Matematika Universitas Katolik Santo Thomas 
Pendidikan Matematika). Vol: 2, No. 1. Html, diakses pada 07 Februari 2018, jam 13:45 WIB.

[30]Slameto. 2017. Belajar dan Faktor-Faktor yang Mempengaruhinya.Jakarta : PT RinekaCipta.

[31]Soemarmo,Utari. 2014. Penilaian Pembelajaran Matematika. Bandung: PT Refika Aditama.

[32]Sudjana, Nana. 2016. Penilaian Hasil Proses Belajar Mengajar.Bandung: PT RemajaRosdakarya Offset.

[33]Susanto Ahmad. 2014. Teori Belajar dan Pembelajaran di SekolahDasar.Jakarta: Kencana Prenada Media Group.

[34]Tampubolon,Saur. 2014. Penelitian Tindakan Kelas Sebagai Pengembangan Profesi Pendidikdan Keilmuan. Jakarta: Erlangga.

[35]Tiska, dkk. 2017. Penerapan Model Pembelajaran Kooperatif Tipe Student Team Achievement Division Untuk Meningkatkan Hasil Belajar Siswa Kelas VII SMP 1 Sindue Tombusabora Pada Materi Persamaan Linear Satu Variabel. Jurnal: Pendidikan Matematika Tadulako.Vol.04.No.04. Html, diakses pada 2 Februari 2019, jam 07:18 WIB.

[36]Trianto. 2011. Mendesain Model Pembelajaran Inovatif-Progresif.Jakarta :Kencana.

[37]Wijaya, Ariyadi.2012. Pendidikan Matematika Realistik Suatu Alternatif Pendekatatan Pembelajaran Matematika.Yogyakarta : Graha Ilmu.

[38]Yezita, dkk. 2012. Mengkonstruksi Pengetahuan Siswa Pada Materi Segitiga Dan segiempat Menggunakan Bahan Ajar Interaktif Matematika Berbasis Konstruktivisme. Jurnal: pendidikan matematika.Vol: 1 No, 1. Html, diakses pada 18 Januari 2019, Jam 11: 56 WIB.

[40]Yezita, dkk. 2012. Mengkonstruksi Pengetahuan Siswa Pada Materi Segitiga Dan segiempat Menggunakan Bahan Ajar Interaktif Matematika Berbasis Konstruktivisme. Jurnal: pendidikan matematika.Vol: 1 No, 1. Html, diakses pada 18 Januari 2019, Jam 11: 56 WIB.

[41]Yohannes. 2017. Penggunaan Media Papan Berpaku Untuk Meningkatkan Hasil Belajar Siswa Dalam Pembelajaranmatematik Materi Bangun Datar Pada Siswa Kelas III SDN SAWIT Sawon, Yogyakarta. Html, diakses pada 2 Maret 2019, jam 20:01 WIB.

[42]Yusuf, A. Muri. 2014. Metode Penelitian. Jakarta: Kencana.

Cartesius: Jurnal Pendidikan Matematika Vol. 2 No. 2

CProdi Pendidikan Matematika Universitas Katolik Santo Thomas 